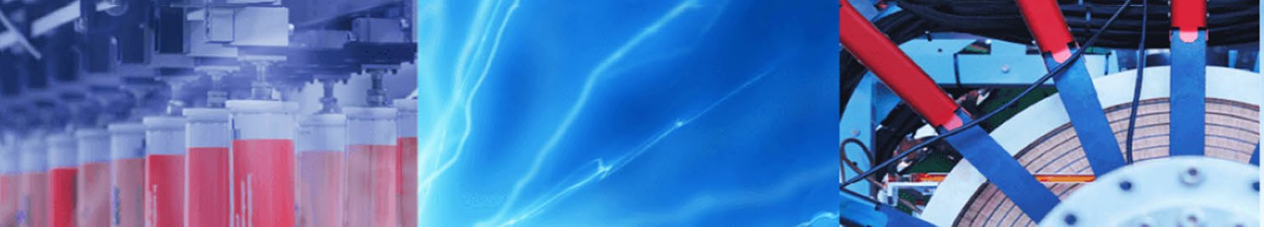

Research Article

\title{
Effectiveness of bagasse ash for performance improvement of asphalt concrete pavements
}

\author{
Asad Zia ${ }^{1,2}$ - Ayaz Ahmad Khan ${ }^{3}$
}

Received: 26 November 2020 / Accepted: 11 March 2021 / Published online: 25 March 2021

(C) The Author(s) 2021 OPEN

\begin{abstract}
The performance of asphalt concrete pavements (ACP) is greatly related to the rate of rutting. Stone dust is mostly used as a filler in ACP. Bagasse ash being cementitious in nature, and costless waste can also be used as a filler. The overall aim is to select a suitable filler for better performance of asphalt concrete pavements. The effectiveness of locally available bagasse ash is examined as a filler for asphalt concrete in terms of its effect on job mix formula, stability, rutting depth, the rise in temperature, and cost of asphalt concrete. All tests are performed as per AASHTO standards. The bagasse ash asphalt concrete showed a reduction in rutting depth, temperature rise, and cost as compared to that of the stone dust asphalt concrete without disturbing the job mix formula. Hence, bagasse ash can be helpful for the performance enhancement of asphalt concrete pavements.
\end{abstract}

Keywords Asphalt concrete pavements · Performance - Bagasse ash $\cdot$ Depth of rutting $\cdot$ Rise in temperature $\cdot$ Cost reduction

\section{Introduction}

As compared to other types of pavements, asphalt concrete pavements (ACP) are considered a better choice in terms of its environmental friendliness [1]. The construction of asphalt concrete pavements is more common than that of concrete pavements under normal circumstances. One of the main flaws responsible for the serviceability decline of the asphalt concrete pavement is an increasing rate of rutting and cracking. Rutting is the primary measure of performance of the pavements in several pavement design methods. The performance of ACP can be enhanced by reducing its rate of rutting. Rutting loosely is defined as longitudinal depressions in wheel paths because of continued densification by the traffic load, which is a type of structural distress in asphalt concrete pavements. Rutting is a serious problem which is resulted due to high thermal conductivity of asphalt and settlement of subgrade material. Rutting causes tearing of tires and affects the load capability of the road as well as the journey feel uncomfortable. In the presence of rutting, the rainwater could not dispose of to the side drains [2].

Mahan [3] and Choudhary et al. [4] reported that the addition of filler to the asphalt mix modified its adhesion and cohesion. It increases the stiffness of the asphalt concrete, enhances its inertia, and improves the rutting resistance of pavements. Filler was found helpful in reducing the asphalt content which increases the lifetime of the mix [5]. The addition of fillers plays a significant role to stiffen asphalt and produced significant improvement in the wearing capabilities of the overall hot mix asphalt (HMA). The wearing capabilities of HMA are enhanced by reducing the sliding movements of asphalt binder over coarse aggregate with the help of an increase in internal friction

$\triangle$ Asad Zia, asad.zia@unich.it; asadzia005@gs.zzu.edu.cn; Ayaz Ahmad Khan, engrayaz50@gmail.com|'Department of Engineering and Geology, Università, Degli Studi G. DAnnunzio Chieti - Pescara, Chieti, Italy. ${ }^{2}$ School of Civil Engineering, Zhengzhou University, Zhengzhou, China. ${ }^{3}$ Department of Civil Engineering, lqra National University, phase 2 Hayatabad Peshawar, Khyber Pakhtunkhwa, Pakistan. 
among them and therefore resist rutting. The filler has also the chemical affinity toward asphalt mix, so it improves the resistance to water access in bitumen [6]. It was investigated that the type of filler had considerable influence on the durability of the bituminous mixtures [7-9]. Various types of materials are investigated as a filler in pavements [10-13]. The clinging nature of filler materials is suggested to help increase the durability of bituminous pavements. Thus, it is required to use such type of cheaper filler material which possesses cementitious and binding properties.

Bagasse ash is disposed out of industries and dumped invaluable lands nearby that mills which create many environmental issues [14]. The bagasse is utilized as a fuel in the sugar industry for the generation of electricity and steam. The burning debris delivered in this procedure is called bagasse ash which has the properties of a pozzolanic material $[15,16]$. It was investigated that the main components of bagasse ashes were some of the mineral oxides which were dominant mineral present in sugarcane [17]. Improvement in mechanical and other properties had been reported by various researchers due to the incorporation of different types of natural materials and their byproducts (fibers and ashes) in concrete and other types of composites [18-21]. It was concluded that the bagasse ash from the sugar industry of the Khyber Pakhtunkhwa, Pakistan, contains unburned carbon, and all constituents present in Portland cement [22]. Thus, the bagasse ash can be used in cement manufacturing as a blend during the process of the clinkerization.

Due to the pozzolanic and binder properties of the bagasse ash, it could be used for the enhancement of the engineering properties of soil [15]. Moreover, the thermal conductivity of bagasse ash was found to be $0.046 \mathrm{~W} / \mathrm{m} . \mathrm{K}$ (0.0265 BTU/(hr. ft $\left.\left.{ }^{\circ} \mathrm{F}\right)\right)$ which was very low as compared to stone dust having thermal conductivity as $1.7 \mathrm{~W} / \mathrm{m} . \mathrm{K}(0.98$ $\left.\mathrm{BTU} /\left(\mathrm{hr} \cdot \mathrm{ft} \cdot{ }^{\circ} \mathrm{F}\right)\right)$ [23]. Hence, it can be considered as a filler in asphalt concrete. It is also used as an engineering raw material for different types of applications. Many authors believed that it could be utilized for preparing lime ash (pozzolanic), mortar, and other building materials, such as blocks and bricks, especially in the water-logged areas where the sugarcane was available at a negligible cost $[24,25]$. It was also reported that bagasse ash due to low emission of carbon dioxide gas could be used in the production of cement with less environmental pollution and low production cost [26]. Moreover, it was reported that bagasse ash might be used as a partial alternative of sand in concrete [22]. Bagasse ash/fly ash-based geopolymer mortar showed good mechanical properties. The compressive strength was in the range of 30 to $50 \mathrm{MPa}$ [28]. Somna et al. [29] reported split tensile strength of $5 \mathrm{~N} / \mathrm{mm}^{2}$ for the $15 \%$ replacement of bagasse ash with ordinary Portland cement. Chi et al. [30] and Ruan et al. [31] reported that inclusion of bagasse ash in concrete triggered a significant amount of decrease in depth of penetration and water permeability. The use of bagasse ash as a construction material solves the environmental pollution and decreases the need of land requirement for dumping the waste bagasse ash [32]. Nowadays, bagasse is normally utilized as a main fuel in all sugar factories of Pakistan as well as in most of the sugar industries of the world.

Researches related to the application of bagasse ash, locally available in Peshawar sugar mills, Khyber Pakhtunkhwa, Pakistan, for asphalt concrete pavements are not available. Therefore, there is a need to carry out an in-depth evaluation of the suitability of local bagasse ash for asphalt concrete pavement. No investigation has been conducted so far, to evaluate the suitability of bagasse ash as a filler for asphalt concrete by checking its effect at the same time on the job mix formula, marshal stability and flow, rutting depth, rise in temperature, and cost of asphalt concrete. Hence, the present research is devoted to the evaluation of the effectiveness of the local bagasse ash as a filler for performance improvement of asphalt concrete pavements. For this purpose, the effectiveness of incorporation of bagasse ash into asphalt concrete is evaluated by investigating its effect simultaneously on the job mix formula, marshal stability and flow, rutting depth, rise in temperature, and cost of asphalt concrete.

\section{Experimental procedure}

\subsection{Raw materials and test area}

Nowshera Industrial Estate, Bara Banda, Nowshera, Khyber Pakhtunkhwa, Pakistan, is selected as a test area. Bitumen and asphalt samples are obtained from the Durrani asphalt plant located at Akora Khattak, Nowshera, Khyber Pakhtunkhwa, Pakistan. On a small scale, it is very difficult and time-consuming to collect a large quantity of bagasse ash. Consequently, the best option for the collection of bagasse ash is nearby sugar mills where a huge quantity of bagasse is burnt to run boiler [22]. For the research, locally available bagasse ash of the Khazana sugar mill (KSM), Peshawar, Khyber Pakhtunkhwa, Pakistan, is used. The chemical composition of the Khazana sugar mill bagasse ash was explored by various researchers [27]. The outcomes of the chemical analysis of the bagasse ash of the KSM are given in Table 1. The chemical analysis showed that the KSM bagasse ash encompasses mainly the $\mathrm{SiO}_{2}(89.4 \%$ average) which plays an important role in increasing the strength of the cement concrete by its cementitious properties. Therefore, the considered KSM bagasse ash is expected to perform well in improving the bond strength of the asphalt concrete with the help of its 
Table 1 Chemical composition of the bagasse ash of the Khazana Sugar mill [27]

\begin{tabular}{llll}
\hline Oxide name & \multicolumn{3}{l}{ Amount in percentage (\%) } \\
\cline { 2 - 4 } & Sample 1 & Sample 2 & Sample 3 \\
\hline $\mathrm{SiO}_{2}$ & 90.09 & 89.89 & 88.36 \\
$\mathrm{Al}_{2} \mathrm{O}_{3}$ & 1.77 & 1.84 & 1.72 \\
$\mathrm{Fe}_{2} \mathrm{O} 3$ & 2.65 & 2.71 & 2.82 \\
$\mathrm{CaO}$ & 2.6 & 2.75 & 2.65 \\
$\mathrm{MgO}$ & 0.66 & 0.72 & 0.62 \\
$\mathrm{Na}_{2} \mathrm{O}$ & 0.28 & 0.27 & 0.25 \\
$\mathrm{~K}_{2} \mathrm{O}$ & 0.32 & 0.35 & 0.32 \\
$\mathrm{SO}_{3}$ & 0.16 & 0.15 & 0.12 \\
& 98.61 & 98.68 & 96.86 \\
\hline
\end{tabular}

clinging properties. The percentage of the $\mathrm{SiO}_{2}$ observed in the bagasse ash conformed with the percentage of the silica reported in the previous studies. The proportions of $\mathrm{SiO}_{2}$ in various types of the bagasse ash reported in different research studies vary from $50-92 \%$. The percentage of $91.3 \%, 75.67 \%, 87.87 \%$, and $87.40 \%$ of silica in the bagasse ash were reported by Bahurudeen and Santhanam [33], Le et al. [34], Katare et al. [35], and Jiménez-Quero et al. [36], respectively.

Approximately $15 \mathrm{~kg}$ (33.06 lbs) bagasse ash is collected in plastic bags from the KSM sugar mill, and then, it is passed through $0.074 \mathrm{~mm}$ sieve (No. 200) to bring it within the specified size of the stone dust and to make it free of dust and other impurities. The cohesion and sticking power of a material are directly related to the plasticity index up to a specified limit. Therefore, $0.074 \mathrm{~mm}$ sieve (No. 200) passed bagasse ash is used to increase its plasticity index by diminishing its size up to a possible limit. Bagasse ash is stored in a dry place to keep it away from the reach of moisture.

\subsection{Test sample for asphalt concrete tests}

Generally, asphalt concrete is composed of bitumen, coarse aggregates, and stone dust as a filler. For this research, the local bagasse ash (of KSM, Peshawar) is used as a filler in asphalt concrete. To prepare samples for extraction and sieve analysis tests, coarse aggregates, bagasse ash, and bitumen of grade $60 / 70$ are used in the proportion of $90.70 \%, 5 \%$, and $4.30 \%$, respectively. The selected proportion of the asphalt concrete is the feasible and commonly practiced proportion for the asphalt pavements of the selected test area, having stone dust as a filler. The above aggregates are mixed with bitumen at $110^{\circ} \mathrm{C}\left(230^{\circ} \mathrm{F}\right)$. Then, this hot mix asphalt concrete is used for extraction and sieve analysis and marshal stability tests [37].
A total of eight samples (four of bagasse ash and four of stone dust) are prepared for wheel tracking tests. Four samples S1, S2, S3, and S4 of asphalt concrete with the coarse aggregates, bagasse ash, and bitumen of grade $(60 / 70)$ in the proportion of $90.70 \%, 5 \%$, and $4.30 \%$, respectively, are cast, while four samples of S5, S6, S7, and $\mathrm{S} 8$ are cast in the same proportion by replacement of bagasse ash with the stone dust in the same ratio. The above aggregates are mixed with the bitumen at $120^{\circ} \mathrm{C}$ $\left(248{ }^{\circ} \mathrm{F}\right)$. Top and bottom plates of molds are heated, and then, hot mix asphalt (HMA) is poured into circular molds having $150 \mathrm{~mm}$ (5.90 inches) diameter and $62 \mathrm{~mm}$ (2.44 inch) thickness. All the samples in molds are made smooth by spatula, and edges are made flat. Then, samples in molds are compacted by standard hammer with 75 blows. Afterward cooling down, the samples are ejected from molds and then submerged in water for $35 \mathrm{~min}$. Next, the external match faces of both specimens are cut such that radius to face is equal to $60 \mathrm{~mm}$ ( $2.36 \mathrm{inch}$ ). All the samples are cleaned with a cloth and are ready for the wheel tracking test.

\subsection{Testing procedure}

The tests performed can be categorized into two classes, i.e., i. preliminary tests on bitumen and ii. principle tests.

\subsubsection{Preliminary tests on bitumen}

All the preliminary tests are performed as per AASHTO standards. Preliminary tests include grade penetration, softening point, flash and fire point, ductility, maximum specific gravity, and bulk specific gravity tests. Grade penetration, softening point, flash and fire point, ductility, maximum specific gravity, and bulk specific gravity tests are performed as per [38-43], respectively.

\subsubsection{Principle tests}

Principle tests are conducted to investigate the effect of bagasse ash on the job mix formula (JMF) of asphalt concrete.

2.3.2.1 Extraction test and sieve analysis AASHTO T-164 [37] is used to perform the extraction test and sieve analysis of asphalt concrete samples of $2.977 \mathrm{~kg}(6.56 \mathrm{lbs})$. Asphalt centrifuge extractor is used for separation of bitumen from asphalt concrete sample, and the set of sieves are used for sieve analysis of aggregates.

2.3.2.2 Air voids, voids in mineral aggregate (Vma), and voids filled with asphalt (Via) AASHTO T-166 [44] is used for determining the bulk specific gravity $(\mathrm{Gmb})$, air 
voids, voids in mineral aggregate (Vma), and voids filled with asphalt $(\mathrm{Vfa})$ of asphalt concrete samples. Asphalt sample of $1.2+0.1 \mathrm{~kg}(2.64+0.2204 \mathrm{lbs})$ is used for one mold, and a total of nine samples are prepared.

2.3.2.3 Marshal stability test This test is carried out as per AASHTO standard T 245 [45]. The test aims to design asphalt paving mixes for determining the economical blend of asphalt and gradation of aggregate to build a good pavement structure [45]. Asphalt sample of $1.2+0.1 \mathrm{~kg}(2.64+0.2204 \mathrm{lbs})$ is used for one mold. A total of nine samples are prepared for this test. All nine molds are kept in a water bath in which three molds are kept for $20 \mathrm{~min}$, three for $30 \mathrm{~min}$, and the other three for $24 \mathrm{~h}$ at $60^{\circ} \mathrm{C}\left(140^{\circ} \mathrm{F}\right)$ to get average results. The marshal stability is computed in terms of the stability in $\mathrm{Kg}(2.204 \mathrm{lbs})$, percent loss of stability, and average flow in $\mathrm{mm}(0.039$ inches).

2.3.2.4 Wheel tracking test Wheel tracking test is performed as per the AASHTO standard T-324 [46]. The samples for wheel tracking tests are prepared as per the AASHTO standard R-30 [47]. This test is used to determine rutting depth by applying a wheel track load with the help of the Hamburg wheel tracking device. The test is repeated for four samples (two samples are used combined) of each of the asphalt concrete samples having bagasse ash as a filler and those having stone dust as a filler each time for 5000 passes to get average results [46]. The rutting depth for each specimen along with the rise in temperature for the specific number of wheel passes is obtained from the wheel tracking test.

\section{Test results and analysis}

\subsection{Results and analysis of preliminary tests on bitumen}

As per the results of the grade penetration test, for the test area Nowshera Industrial Estate, Bara Banda, Nowshera, Khyber Pakhtunkhwa, the bitumen of grade $60 / 70$ is found suitable. The results for preliminary tests of the selected bitumen are given in Table 2 from the first column to the seventh column. The values of $48.50^{\circ} \mathrm{C}\left(119.3^{\circ} \mathrm{F}\right), 232^{\circ} \mathrm{C}$ $\left(450^{\circ} \mathrm{F}\right), 415^{\circ} \mathrm{C}\left(779^{\circ} \mathrm{F}\right), 102 \mathrm{~cm}$ (40.15 inches), 2.51, 2.385, $4.9 \%, 14.51 \%$, and $66.2 \%$ are noticed for softening point, flash and fire point, ductility (in terms of rapture distance), average maximum specific gravity of bitumen, and average bulk specific gravity of the bitumen, respectively. The results of the softening point test, flash and fire point test, ductility test (in terms of rapture distance), average maximum specific gravity, and average bulk specific gravity

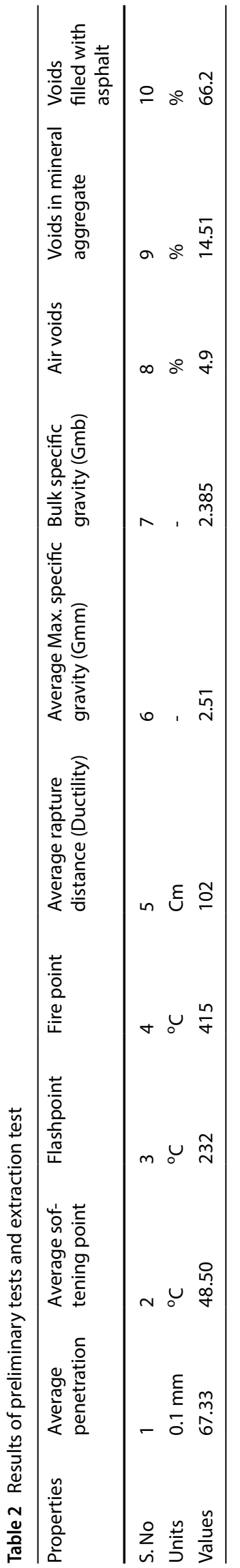


of bitumen tests also conformed the grade $60 / 70$ of the selected bitumen.

\subsection{Results and analysis of principle tests}

\subsubsection{Extraction and sieve analysis}

This test is used to find the percentage of bitumen in asphalt concrete [37]. An oven-dried asphalt mix of $2.9 \mathrm{~kg}(6.39 \mathrm{lbs})$ is kept in the extraction machine, and the amount of bitumen is calculated by the process of extraction. The bitumen percentage is found equal to $4.30 \%$. The coarse aggregates separated from bitumen are analyzed for sieve analysis. The passing of $100 \%, 85.40 \%, 71 \%$, $51.70 \%, 33.5 \%, 11.90 \%$, and $4.40 \%$ is observed for $19.0 \mathrm{~mm}$ (3/4 inch), $12.7 \mathrm{~mm}$ (1/2 inch), $9.51 \mathrm{~mm}$ (3/8 inch), $4.76 \mathrm{~mm}$ (No. 4), $2.38 \mathrm{~mm}$ (No. 8), $0.297 \mathrm{~mm}$ (No.50), and $0.074 \mathrm{~mm}$ (No. 200) sieves, respectively. The range set by AASHTO T-164 is $100 \%, 75$ to $89 \%, 63$ to $77 \%, 41$ to $55 \%, 28$ to $36 \%$, 7 to $15 \%$, and 3 to $8 \%$ for $19.0 \mathrm{~mm}$ (3/4 inch), $12.7 \mathrm{~mm}$ (1/2 inch), $9.51 \mathrm{~mm}$ (3/8 inch), $4.76 \mathrm{~mm}$ (No. 4), $2.38 \mathrm{~mm}$ (No. 8), $0.297 \mathrm{~mm}$ (No. 50), and $0.074 \mathrm{~mm}$ (No. 200) sieves, respectively. The sieve analysis showed that the percentage passing of aggregates from a concerned sieve is within the limits specified by AASHTO T- 164 .

The graph drawn between percent passing and sieve sizes is shown in Fig. 1. The lower limit and upper limits specified by AASHTO for each size of the sieve are also shown by the curve. It is clear from the graph that the actual passing of each sieve occurred between the lower and upper limits specified by AASHTO T-164. Thus, the compliance of bitumen extraction and sieve analysis test confirms that the use of bagasse ash as a filler will not disturb the job mix formula.

\subsubsection{Air voids, voids in mineral aggregate (Vma), and voids filled with asphalt ( $\mathrm{Vfa}$ )}

The air voids, voids in mineral aggregate (Vma), and voids filled with asphalt (Vfa) for the asphalt concrete specimens are presented in Table 2. By using the values of $\mathrm{Gmb}$ and $\mathrm{Gmm}$, the percentage of air voids is computed as $4.9 \%$, which comply with the limits (i.e., $3 \%$ to $8 \%$ for wearing course) specified by the AASHTO for air voids. The value of Vma came out to be $14.51 \%$, which is less than the percentage (i.e., $16 \%$ ) specified by AASHTO for wearing course. Hence, the percentage of voids in mineral aggregates can be reduced by the use of bagasse ash. Likewise, the value of voids filled with asphalt ( $\mathrm{Vfa}$ ) that is $66.2 \%$ also conforms to the range ( $65 \%$ to $75 \%$ ) specified by AASHTO for wearing course. Hence, it can be concluded based on the results of air voids, Vma, and Vfa that the incorporation of bagasse ash in asphalt concrete will not disturb its job mix formula and can help make the asphalt concrete less porous and compact.

\subsubsection{Marshal stability of the bagasse ash asphalt concrete}

The stability is defined as the maximum load carried by the asphalt sample at a temperature of $60^{\circ} \mathrm{C}\left(140^{\circ} \mathrm{C}\right)$. The stability of asphalt concrete should be equal to or less than $1000 \mathrm{~kg}$ (2204 lbs) [45]. The flow is measured as the deformation in a sample from zero loadings to maximum loading. The results obtained from the marshal stability tests are shown in Table 3.

The average stability of a set of the three samples for each of the soaking period of $20 \mathrm{~min}, 30 \mathrm{~min}$, and $24 \mathrm{~h}$ is $1485 \mathrm{~kg}$ (3273 lbs), $1352 \mathrm{~kg}$ (2980 lbs), and $1288 \mathrm{~kg}(2839$ lbs), respectively. The average stability for every three
Fig. 1 Percent passing for each sieve size

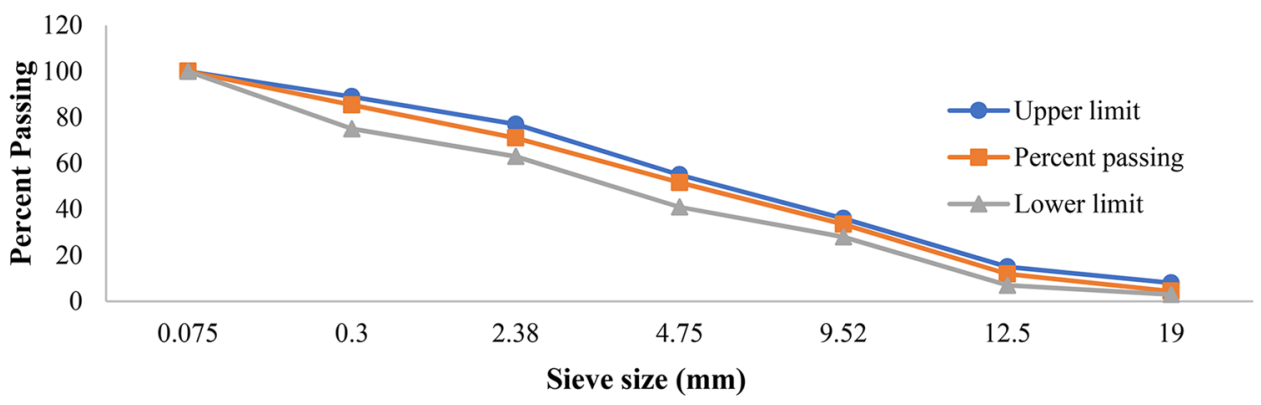

Table 3 Marshal stability of the bagasse ash asphalt concrete samples

\begin{tabular}{|c|c|c|c|c|c|c|c|c|c|}
\hline \multirow{2}{*}{$\begin{array}{l}\text { Soaking period } \\
\text { Samples }\end{array}$} & \multicolumn{3}{|c|}{$20 \mathrm{~min}$} & \multicolumn{3}{|c|}{$30 \mathrm{~min}$} & \multicolumn{3}{|l|}{$24 \mathrm{~h}$} \\
\hline & 1 & 2 & 3 & 4 & 5 & 6 & 7 & 8 & 9 \\
\hline Stability (kg) & 1410 & 1490 & 1555 & 1401 & 1350 & 1305 & 1300 & 1267 & 1298 \\
\hline Avg. stability (kg) & 1485 & & & 1352 & & & 1288 & & \\
\hline Flow $(0.25 \mathrm{~mm})$ & 10 & 8 & 7 & 10 & 10 & 11 & 11 & 12 & 11 \\
\hline
\end{tabular}


samples falls within the range (equal or greater than 1000 kg "2204 lbs") specified by AASHTOT 245. The loss of stability is $13.2 \%$, which fulfilled the criteria specified by AASHTO for a stable asphalt mix. The average of the flows of all specimens is found " 10 " in $0.25 \mathrm{~mm}$ (0.0098 inches) which also confirmed the range specified by AASHTOT 245 for stable mix design of asphalt concrete. Hence, all the results of the marshal stability test supported the suitability of the use of bagasse ash as a filler for asphalt concrete pavements in terms of stability and flow. It can be concluded that the addition of the bagasse ash into asphalt concrete can help sustain the stability of the asphalt concrete pavements against the deformation due to applied loads.

\subsubsection{Rutting depth and temperature rise of asphalt concrete pavement samples}

The condition of asphalt concrete samples of a wheel tracking test is shown in Fig. 2. Here, in this work, information regarding the number, locations, and length of cracks are noticed after performing the wheel tracking test. The crack which extends to about total length and $80 \%$ of the depth of the sample is observed in the stone dust asphalt concrete sample as shown in Fig. 4, while in the case of bagasse ash asphalt concrete samples, cracks are produced, and the samples remain uncracked for the same number of passes with the separation of the slight number of particles from the samples. The stone dust asphalt concrete samples showed shear failure, and some portion of the sample bulged out when removed from the mold after the test. The samples of bagasse ash that did not shatter into pieces neither showed shear failure nor showed a relative ductile/tough behavior against the wheel passes. The high ductility and good binding properties of bagasse ash increased the capacity of the bagasse ash samples to resist the cracks' propagation without significant deformation.

The rutting depth and rise in temperature obtained for each asphalt concrete specimen are given in Table 4.
Table 4 Rutting depth and temperature rise

\begin{tabular}{lllll}
\hline Sample & $\begin{array}{l}\text { No of passes } \\
(\text { Nos })\end{array}$ & $\begin{array}{l}\text { Rutting } \\
\text { depth } \\
(\mathrm{mm})\end{array}$ & $\begin{array}{l}\text { Initial } \\
\text { temp } \\
\left({ }^{\circ} \mathrm{C}\right)\end{array}$ & $\begin{array}{l}\text { Final } \\
\text { temp } \\
\left({ }^{\circ} \mathrm{C}\right)\end{array}$ \\
\hline $\begin{array}{l}\text { Bagasse ash } \\
\text { samples }\end{array}$ & - & - & - & - \\
S1 & 5000 & 5 & 54 & 59 \\
S2 & 10,000 & 8 & 54 & 64 \\
S3 & 15,000 & 12 & 54 & 69 \\
S4 & 20,000 & 15 & 54 & 75 \\
Stone dust sam- & - & - & - & - \\
ples & & 7 & 54 & 60 \\
S5 & 5000 & 12 & 54 & 66 \\
S6 & 10,000 & 16 & 54 & 73 \\
S7 & 15,000 & 20 & 54 & 81 \\
S8 & 20,000 & & &
\end{tabular}

The rutting depth of the S1, S2, S3, and S4 having bagasse ash as a filler is $5 \mathrm{~mm}$ (0.196 inches), $8 \mathrm{~mm}$ (0.315 inches), $12 \mathrm{~mm}$ (0.472 inches), and $15 \mathrm{~mm}$ (0.590 inches), respectively, while the rutting depths of $7 \mathrm{~mm}$ (0.275 inches), $12 \mathrm{~mm}$ (0.472 inches), $16 \mathrm{~mm}(0.630$ inches), and $20 \mathrm{~mm}$ ( 0.787 inches) are observed for S5, $\mathrm{S6}, \mathrm{S7}$, and $\mathrm{S} 8$, respectively.

The rutting depths of $\mathrm{S} 1, \mathrm{~S} 2, \mathrm{~S} 3$, and $\mathrm{S} 4$ are found $2 \mathrm{~mm}$ (0.0.078 inch), $4 \mathrm{~mm}$ (0.157 inches), $4 \mathrm{~mm}$ (0.157 inches), and $5 \mathrm{~mm}$ (0.196 inches), less than that of the S5, S6, S7, and S8, respectively. The average value for rutting depth of the samples of asphalt concrete having bagasse ash as a filler is $10 \mathrm{~mm}$ (0.393 inches), while that of the samples having stone dust as a filler is $13.75 \mathrm{~mm}$ ( 0.541 inches). This showed that the average rutting depth for asphalt concrete having bagasse ash as a filler is $3.75 \mathrm{~mm}$ (0.147 inches) less than that stone dust samples. The decline in the rutting depth for bagasse ash samples may be due to the high ductility of bagasse ash as compared to that of stone dust.

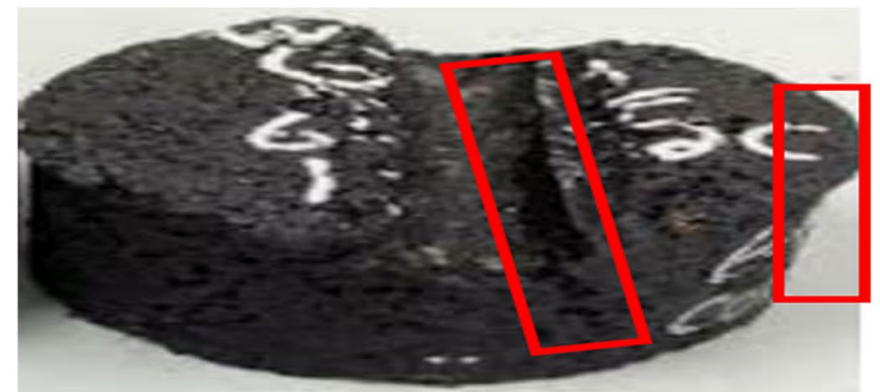

a

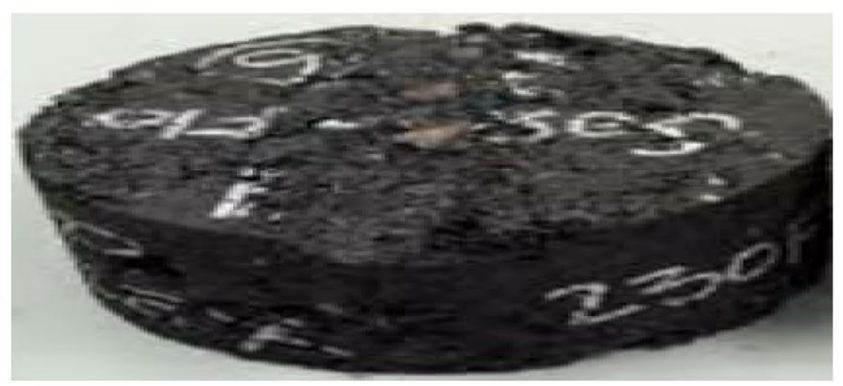

b

Fig. 2 Cracks in asphalt concrete samples of wheel tracking test a. stone dust sample and b. bagasse ash sample 


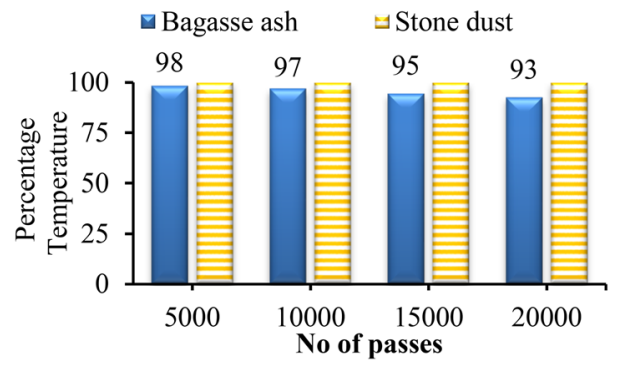

Fig. 3 Comparison of temperature rise of bagasse ash samples and stone dust samples

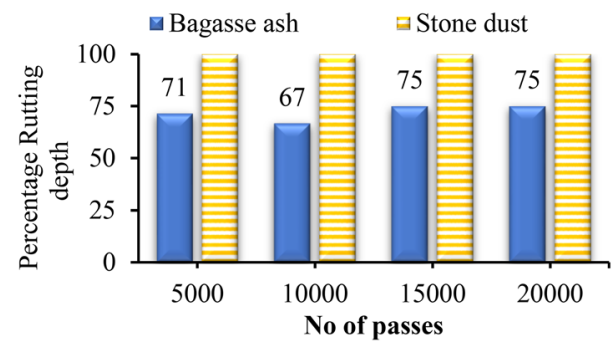

Fig. 4 Comparison of rutting depth of bagasse ash samples and stone dust samples

The initial temperature for all asphalt concrete samples is $54^{\circ} \mathrm{C}\left(129.2^{\circ} \mathrm{F}\right)$. The final temperature for the sample 1 (S1), sample 2 (S2), sample 3 (S3), and sample 4 (S4) having bagasse ash as a filler is $59^{\circ} \mathrm{C}\left(138.2^{\circ} \mathrm{F}\right), 64^{\circ} \mathrm{C}\left(147.2^{\circ} \mathrm{F}\right)$, $69^{\circ} \mathrm{C}\left(156.2^{\circ} \mathrm{F}\right)$, and $75^{\circ} \mathrm{C}\left(167^{\circ} \mathrm{F}\right)$, respectively. Thus, rises in temperature of $5^{\circ} \mathrm{C}\left(41^{\circ} \mathrm{F}\right), 12$ oC $\left(53.6^{\circ} \mathrm{F}\right), 15$ oC $\left(59^{\circ} \mathrm{F}\right)$, and $21^{\circ} \mathrm{C}\left(69.8^{\circ} \mathrm{F}\right)$ are noticed for the bagasse ash samples of $\mathrm{S} 1, \mathrm{~S} 2, \mathrm{~S} 3$, and $\mathrm{S} 4$, respectively. The final temperatures for the sample 5 (S5), sample 6 (S6), sample 7 (S7), and sample 8 (S8) having stone dust as a filler are $60^{\circ} \mathrm{C}(140$ $\left.{ }^{\circ} \mathrm{F}\right), 66^{\circ} \mathrm{C}\left(150.8{ }^{\circ} \mathrm{F}\right), 73^{\circ} \mathrm{C}\left(163.2^{\circ} \mathrm{F}\right)$, and $81^{\circ} \mathrm{C}\left(177.8^{\circ} \mathrm{F}\right)$, respectively.

Consequently, the rises in temperature are $6^{\circ} \mathrm{C}\left(42.8^{\circ} \mathrm{F}\right)$, $14 \mathrm{oC}\left(57.2^{\circ} \mathrm{F}\right), 19 \mathrm{oC}\left(66.2^{\circ} \mathrm{F}\right)$, and $27^{\circ} \mathrm{C}\left(80.6^{\circ} \mathrm{F}\right)$, for the $\mathrm{S} 5, \mathrm{~S} 6, \mathrm{S7}$, and $\mathrm{S} 8$, respectively. The rises in temperature of $\mathrm{S} 1, \mathrm{~S} 2, \mathrm{~S} 3$, and $\mathrm{S} 4$ are lesser than that of the $\mathrm{S} 5, \mathrm{~S} 6, \mathrm{~S} 7$, and S8 by an amount of 1 oC $\left(33.8^{\circ} \mathrm{F}\right), 2$ oC $\left(35.6^{\circ} \mathrm{F}\right), 4 \mathrm{oC}(39.2$ $\left.{ }^{\circ} \mathrm{F}\right)$, and $6 \circ \mathrm{OC}\left(42.8^{\circ} \mathrm{F}\right)$, respectively. The average value of final temperatures of all bagasse ash samples is $66.75^{\circ} \mathrm{C}$ $\left(152.15^{\circ} \mathrm{F}\right)$ and that of stone dust samples is $70^{\circ} \mathrm{C}\left(158^{\circ} \mathrm{F}\right)$. The average rise in temperature for bagasse ash samples is $3.25^{\circ} \mathrm{C}\left(37.85^{\circ} \mathrm{F}\right)$ less than that of stone dust samples. The small temperature rise of the bagasse ash asphalt concrete can be attributed to the low thermal conductivity of bagasse ash.

The mutual comparison among the rutting depths of bagasse ash samples and stone dust samples is displayed in Fig. 3. As compared to rutting depth of stone dust samples, the decrease of $29 \%, 33 \%, 25 \%$, and $25 \%$ are noticed in the rutting depth of corresponding bagasse ash samples for the same number of passes of 5000, 10,000, 15,000 , and 20,000, respectively. The largest decline (33\%) in the rutting depth of the bagasse ash sample as compared to that of the stone dust sample occurred at 10,000 number of passes. In each case, the significant decline is noticed in the rutting depth of the bagasse ash sample than that of the stone dust sample.

The rise in temperatures of the bagasse ash samples and stone dust samples is demonstrated in Fig. 4 for the respective number of passes. The temperature rise for bagasse ash samples is lower than that of stone dust samples. The temperature rises of bagasse ash samples reduced by $2 \%, 3 \%, 5 \%$, and $7 \%$ for the number of passes of $5000,10,000,15,000$, and 20,000, respectively, as compared to that of stone dust samples for the same number of passes. The reduced rutting depth and decrease in the rise of temperature showed that the bagasse ash as a filler has the potential to perform better than stone dust in the performance improvement of asphalt concrete pavements.

The significant amount of decline is observed in the rutting depth and temperature rise of bagasse ash asphalt concrete samples in contrast to their companions having stone dust as a filler. The clinging and sticky nature of bagasse ash may strengthen the bond among the ingredients of the composite. As a result, resistance to rutting of bagasse ash samples may be enhanced. The reduction in the temperature rise of bagasse ash samples can be due to less heat conductivity of the bagasse ash. This possibly will be the combined effect of cementitious nature and low heat conductivity of the bagasse ash, which imparted strong bonds and enhanced heat conductance resistance to the asphalt concrete samples. Thus, the serviceability of asphalt concrete pavements can be improved by using bagasse ash as a filler.

\section{Discussion}

\subsection{Relationship between material properties and asphalt concrete pavement performance}

Better performance of asphalt concrete pavements (ACP) greatly depends upon the properties and durability of filler materials. Among the available types of filler materials, stone dust is mostly used as a filler in the ACP [3]. Stone dust is an inert material with negligible cementitious properties like fine aggregates. Due to this trend, the bond between stone dust and aggregates in the asphalt pavements is not much effective in resisting abrasion caused by vehicle movement [48]. Thus, it is required to use such 
type of filler that has the potential to create a strong bond with the aggregates. Hence, the effectiveness of available low-cost cementitious material for better performance of ACP needs to be explored in detail. Bagasse ash being cementitious in nature can be helpful in this respect [49].

Therefore, in this pilot study, the application of local bagasse ash for performance improvement of the asphalt concrete pavements is considered. The effect of locally available bagasse ash on the job mix formula, the rutting depth, rise in temperature, and cost of asphalt concrete samples having bagasse ash as a filler is experimentally evaluated. Asphalt concrete having stone dust as a filler is used for comparison purpose. As per the outcomes, the addition of bagasse ash as a filler did not affect the job mix formula. In addition to it, the asphalt concrete having bagasse ash as a filler outperformed the companion having stone dust as a filler in reducing the temperature rise, rutting depth, and cost of asphalt concrete. Accordingly, in the case of bagasse ash samples, the performance of ACP can be better; conclusively, it is highly likely to improve the performance of ACP.

\subsection{Cost comparison of bagasse ash and stone dust}

Costs of bagasse ash asphalt concrete (BAC) and stone dust asphalt concrete (SAC) are given in Table 5. The costs are calculated as per the local market rates of Nowshera, Khyber Pakhtunkhwa, Pakistan, 2019. The estimated cost of each material is computed without considering the cost of labor and transportation. Bagasse ash being waste and pollutant of the sugar mills cost zero. The cost of stone dust is 2.1 US Dollar (USD) per 2.83 cubic meters " $100 \mathrm{ft}^{3}$ ". The 2.83 cubic meter ( 100 $\mathrm{ft}^{3}$ ) bitumen carries the highest cost of 3777.1 USD as compared to other ingredients of the asphalt concrete. The total cost of one cubic meter $\left(35.28 \mathrm{ft}^{3}\right)$ of the BAC and SAC is 60.82 USD and 60.86 USD, respectively. The cost of $1 \mathrm{~m}^{3}\left(35.28 \mathrm{ft}^{3}\right)$ of BAC is 0.04 USD less than that of SAC of the same volume. For one-kilometer (3280 foot) asphalt concrete road of width $6 \mathrm{~m}$ (19.68 foot) and thickness $0.06 \mathrm{~m}(60 \mathrm{~mm})$ "0.196 foot," a total amount of 14.4 USD can be saved using BAC. It showed that the BAC pavements are more economical than that of SAC pavements.

The percentage cost comparison of bagasse ash asphalt concrete (BAC) and stone dust asphalt concrete (SAC) is shown in the last row of Table 5. The cost of BAC of $1 \mathrm{~m}^{3}$ $\left(35.28 \mathrm{ft}^{3}\right)$ is about $0.1 \%$ less than that of the $1 \mathrm{~m}^{3}(35.28$ $\mathrm{ft}^{3}$ ) SAC. Accordingly, the idea of replacement of the stone dust with the bagasse ash as a filler in asphalt concrete pavements can also be supported by a considerable amount of cost reduction of the BAC on a large production basis. Thus, the BAC can be helpful in the cost reduction of the asphalt concrete pavements.

\section{Conclusions}

The role of filler for the performance improvement of asphalt concrete pavements (ACP) by decreasing the rate of rutting, rise in temperature, and cost-effectiveness is discussed. Stone dust is commonly used as a filler in ACP. The cementitious and temperature resistant of filler play a vital role in the better performance of ACP. The bagasse ash being cementitious in nature with high resistance to heat conductance is available in an abundant amount. In this research, the experimental behaviors of asphalt concrete having bagasse ash as a filler are evaluated to check their suitability to control the depth of rutting, rise in temperature, and construction cost. The properties of asphalt concrete having stone dust as a filler are taken as a reference. The bagasse ash samples of asphalt concrete are prepared by the addition of $5 \%$ content of bagasse ash, in the same mix proportion of stone dust samples of asphalt concrete, i.e., coarse aggregates and bitumen of grade $60 / 70$ in a proportion of about $90.70 \%$ and $4.30 \%$, respectively. Following results are detected during the investigation:
Table 5 Cost per 1 cubic meter of stone dust (SD) and bagasse ash (BA) asphalt concrete

\begin{tabular}{|c|c|c|c|c|c|}
\hline \multirow[t]{2}{*}{ S. No } & \multirow[t]{2}{*}{ Materials } & \multirow[t]{2}{*}{ Quantity $\left(\mathrm{m}^{3}\right)$} & \multirow{2}{*}{$\begin{array}{l}\text { Rate per } \\
2.83 \mathrm{~m}^{3} \\
\text { (USD) }\end{array}$} & \multicolumn{2}{|c|}{$\begin{array}{l}\text { Cost per } 1 \text { cubic meter } \\
\text { (USD) }\end{array}$} \\
\hline & & & & $\begin{array}{l}\text { BA asphalt } \\
\text { concrete }\end{array}$ & $\begin{array}{l}\text { SD asphalt } \\
\text { concrete }\end{array}$ \\
\hline 1 & Coarse aggregate & 0.907 & 10.7 & 3.43 & 3.43 \\
\hline 2 & Bitumen & 0.043 & 3777.1 & 57.39 & 57.39 \\
\hline 3 & Stone dust & 0.050 & 2.1 & - & 0.04 \\
\hline 4 & Bagasse ash & 0.050 & 0 & 0 & - \\
\hline Total cost (USD) & & & & 60.82 & 60.86 \\
\hline Percentage comparison (\%) & & & & 99.9 & 100 \\
\hline
\end{tabular}


- The percentage of air voids, voids in mineral aggregate $(\mathrm{Vma})$, and voids filled with asphalt $(\mathrm{Vfa})$ is $4.9 \%$, $14.51 \%$, and $66.2 \%$, respectively. The air voids, Vma, and Vfa complied with the limits specified by the AASHTO for each of them. Hence, the use of bagasse ash will not disturb the job mix formula.

- The average stability for every three samples falls within the range (equal or greater than $1000 \mathrm{~kg}$ ) specified by AASHTO and ASTM specifications. Moreover, the loss of stability is $13.2 \%$, which also fulfilled the criteria specified by AASHTO specifications for a stable asphalt mix. Also, the resulted average flow of 10 in $0.25 \mathrm{~mm}$ (0.0098 inches) for the bagasse ash asphalt concrete followed the range specified by AASHTO specifications.

- In contrast to rutting depth of stone dust samples of S1, $\mathrm{S} 2, \mathrm{~S} 3$, and S4, the rutting depths of bagasse ash samples of S5, S6, S7, and S8 are reduced by $29 \%, 33 \%, 25 \%$, and $25 \%$, respectively, for the same number of wheel passes of $5000,10,000,15,000$, and 20,000, respectively.

- The temperature rise of bagasse ash samples is smaller than that of stone dust samples. The temperature rise of bagasse ash samples decreased by $2 \%, 3 \%, 5 \%$, and $7 \%$ for the number of wheel passes of 5000, 10,000, 15,000 , and 20,000 , respectively, as compared to that of stone dust samples for the same number of wheel passes.

- The cost of bagasse ash asphalt concrete of 1 cubic meter $\left(35.28 \mathrm{ft}^{3}\right)$ is reduced by about $0.1 \%$ than that of 1 cubic meter $\left(35.28 \mathrm{ft}^{3}\right)$ of stone dust asphalt concrete.

Based on the conclusions and studied properties, bagasse ash as a filler in asphalt concrete pavement is expected to help control the depth of rutting, rise in temperature, and construction cost of asphalt concrete pavements. The durability and optimized content of bagasse ash need to be explored for additional improvement. Further investigations are also required to compare the effectiveness of bagasse ash as a filler with other types of local fillers for asphalt concrete road.

Acknowledgement The authors would like to extend their acknowledgment to all persons who helped them throughout the research work.

Authors' contributions Contributions of the first author include literature review, analysis of test results, revision of the draft, and preparation of the final finished draft. Second author conducted the experimental laboratory work and initial draft.

Code availability Not applicable.

\section{Compliance with ethical standards}

Conflicts of interest On behalf of all authors, the corresponding author states that there is no conflict of interest.
Availability of data and material Not applicable.

Open Access This article is licensed under a Creative Commons Attribution 4.0 International License, which permits use, sharing, adaptation, distribution and reproduction in any medium or format, as long as you give appropriate credit to the original author(s) and the source, provide a link to the Creative Commons licence, and indicate if changes were made. The images or other third party material in this article are included in the article's Creative Commons licence, unless indicated otherwise in a credit line to the material. If material is not included in the article's Creative Commons licence and your intended use is not permitted by statutory regulation or exceeds the permitted use, you will need to obtain permission directly from the copyright holder. To view a copy of this licence, visit http://creativecommons. org/licenses/by/4.0/.

\section{References}

1. Horvath A, Hendrickson C (1998) Comparison of environmental implications of asphalt and steel-reinforced concrete pavements. Trans Res Rec 1626(1):105-113

2. Yavuzturk C, Ksaibati K, Chiasson AD (2005) Assessment of temperature fluctuations in asphalt pavements due to thermal environmental conditions using a two-dimensional, transient finite-difference approach. J Mater Civil Eng 17(4):465-475

3. Mahan HM (2013) Influence of mineral filler-asphalt ratio on asphalt mixture performance. J Babylon Univ Eng Sci 21(4):1213-1222

4. Choudhary J, Kumar B, Gupta A (2020) Utilization of solid waste materials as alternative fillers in asphalt mixes: a review. Const Build Mater 234:117271

5. Hafeez I, Kamal MA (2010) Effects of mineral filler to polymer modified bitumen ratio on the design properties of hot mix asphalt and its performance. Mehran Univ Res J Eng Technol 29(4):581-588. http://www.academia.edu/download/63838 33/pdf40.pdf

6. Recasens R, Martínez A, Jiménez F, Bianchetto H (2005) Effect of filler on the aging potential of asphalt mixtures. Trans Res Rec J Trans Res Board 1901:10-17

7. Craus J, Ishai I, Sides A (1978) Some physicochemical aspects of the effect and the role of the filler in bituminous paving mixtures. Association of Asphalt Paving Technologists Proc Vol. 47. https://trid.trb.org/view/92178

8. Kadeyali (1997). Principles and practice of highway engineering, 3rd edn.

9. Zulkati A, Diew WY, Delai DS (2011) Effects of fillers on properties of asphalt-concrete mixture. J Transp Eng 138(7):902-910. https://doi.org/10.1061/(ASCE)TE.1943-5436.0000395

10. Asi I, Assaad A (2005) Effect of Jordanian oil shale fly ash on asphalt mixes. J Mater Civil Eng 17(5):553-559

11. Hwang SD, Park HM (2005) A Study on engineering characteristics of asphalt concrete mixtures using filler with recycled waste lime. Int J Highway Eng 7(3):71-78. https://doi.org/10. 1016/j.wasman.2006.11.011

12. Xue Y, Hou H, Zhu S, Zha J (2009) Utilization of municipal solid waste incineration ash in stone mastic asphalt mixture: pavement performance and environmental impact. Const Build Mater 23(2):989-996

13. Lin DF, Lin JD, Chen SH (2006) The application of baghouse fines in Taiwan. Resour Conser Recycl 46(3):281-301. https:// doi.org/10.1016/j.resconrec.2005.08.002 
14. Cokca E, Yazici V, Ozaydin V (2009) Stabilization of expansive clays using granulated blast furnace slag (GBFS) and GBFScement. Geotech Geol Eng 27(4):489. https://doi.org/10.1007/ s10706-008-9250-z

15. Janjaturaphan S, Wansom S (2010) Pozzolanic activity of industrial sugar cane bagasse ash. Suranaree J Sci Technol 17(4): 349-357. https://core.ac.uk/download/pdf/70937778. pdf

16. Paya J, Monzo J, Borrachero MV, Diaz-Pinzon L, Ordonez LM (2002) Sugarcane bagasse ash (SCBA): studies on its properties for reusing in concrete production. J Chem Technol Biotechnol 77(3):321-325. https://doi.org/10.1002/jctb.549

17. Suliman ME, Almola SMF (2011) The use of sugarcane bagasse ash as an alternative local pozzolanic material: study of chemical composition. Sci Vis 16(17):65-70

18. Khan MA, Zia A, Sadiq MM, Pu Z (2018) Suitability of partial replacement of cement with sugarcane bagasse ash and sand with stone dust for concrete. NED Univ J Res 15(1):51-61

19. Zia A, Ali M (2017) Behavior of fiber reinforced concrete for controlling the rate of cracking in canal-lining. Const Build Mater 155:726-739. https://doi.org/10.1016/j.conbuildmat.2017.08.078

20. Khan M, Ali M (2019) Improvement in concrete behavior with fly ash, silica-fume and coconut fibres. Const Build Mater 203:174-187

21. Ruano G, Bellomo F, López G, Bertuzzi A, Nallim L, Oller S (2020) Mechanical behaviour of cementitious composites reinforced with bagasse and hemp fibers. Const Build Mater 240:117856

22. Ali K, Amin NU, Shah MT (2009) Physicochemical study of bagasse and bagasse ash from the sugar industries of NWFP, Pakistan and its recycling in cement manufacturing. J Chem Soc Pak 31(3):375378. https://inis.iaea.org/search/search.aspx?orig_q=RN:40093152

23. Madurwar MV, Mandavgane SA, Ralegaonkar RV (2014) Development and feasibility analysis of bagasse ash bricks. J Energy Eng 141(3):04014022. https://doi.org/10.1061/(ASCE)EY.1943-7897. 0000200

24. Kazmi SM, Abbas S, Saleem MA, Munir MJ, Khitab A (2016) Manufacturing of sustainable clay bricks: utilization of waste sugarcane bagasse and rice husk ashes. Const Build Mater 120:29-41

25. Castaldelli VN, Akasaki JL, Melges JL, Tashima MM, Soriano L, Borrachero MV, Payá J (2013) Use of slag/sugar cane bagasse ash (SCBA) blends in the production of alkali-activated materials. Materials 6(8):3108-3127. https://doi.org/10.3390/ma6083108

26. Bahurudeen A, Santhanam M (2014) Performance evaluation of sugarcane bagasse ash-based cement for durable concrete. In: Proceedings of the 4 th international conference on the durability of concrete structures, 24-26 July 2014 Purdue University, West Lafayette, USA. https://www.researchgate.net/publication/26916 5176_Performance_Evaluation_of_Sugarcane_Bagasse_AshBased Cement for Durable Concrete

27. Ali K, Noor-ul-Amin, Shah T, Saeed-ur-Rehman (2010) Physicochemical study of bagasse and bagasse ash from the sugar industries of NWFP Pakistan and remediation of environmental problems caused by refused bagasse ash. Survival and Sustainability, pp 1225-1235. Springer, Berlin, Heidelberg. Doi:https://doi.org/ 10.1007/978-3-540-95991-5_115

28. Ganesan K, Rajagopal K, Thangavel K (2007) Evaluation of bagasse ash as supplementary cementitious material. Cem Conc Comp 29(6):515-524. https://doi.org/10.1016/j.cemconcomp.2007.03. 001

29. Somna R, Jaturapitakkul C, Amde AM (2012) Effect of ground fly ash and ground bagasse ash on the durability of recycled aggregate concrete. Cem Conc Comp 34(7):848-854. https://doi.org/10. 1016/j.cemconcomp.2012.03.003

30. Chi M, Huang R, Yeih WC (2015) Physical and mechanical properties of cement-based composites with bagasse ash. J Mar Sci Technol 23(1):1-7. https://doi.org/10.6119/JMST-013-0717-1
31. Ruan S, Zhu W, Yang EH, Weng Y, Unluer C (2020) Improvement of the performance and microstructural development of alkaliactivated slag blends. Const Build Mater 261:120017. https://doi. org/10.1016/j.conbuildmat.2020.120017

32. Gu G, Xu F, Ruan S, Huang X, Zhu J, Peng C (2020) Influence of precast foam on the pore structure and properties of fly ash-based geopolymer foams. Const Build Mater 256:119410. https://doi.org/ 10.1016/j.conbuildmat.2020.119410

33. Bahurudeen A, Santhanam M (2015) Influence of different processing methods on the pozzolanic performance of sugarcane bagasse ash. Cem Conc Comp 56:32-45. https://doi.org/10.1016/j. cemconcomp.2014.11.002

34. Le DH, Sheen YN, Lam MNT (2018) Fresh and hardened properties of self-compacting concrete with sugarcane bagasse ash-slag blended cement. Const Build Mater 185:138-147. https://doi.org/ 10.1016/j.conbuildmat.2018.07.029

35. Katare VD, Madurwar MV (2017) Experimental characterization of sugarcane biomass ash: a review. Const Build Mater 152:1-15. https://doi.org/10.1016/j.conbuildmat.2017.06.142

36. Jiménez-Quero VG, León-Martínez FM, Montes-Garcia P, GaonaTiburcio C, Chacón-Nava JG (2013) Influence of sugar-cane bagasse ash and fly ash on the rheological behavior of cement pastes and mortars. Const Build Mater 40:691-701. https://doi. org/10.1016/j.conbuildmat.2012.11.023

37. AASHTO T-164 (2014) Standard method of test for quantitative extraction of asphalt binder from hot mix asphalt (HMA). American Association of State Highway and Transportation Officials, Washington, DC. https://standards.globalspec.com/std/13053 329/AASHTO\%20T\%20164

38. AASHTO M 20 (2000) 70th Edition, 2000: Standard specification for penetration-graded asphalt cement. American Association of State and Highway Transportation Officials.

39. AASHTO T 53 (2009) 2009 Edition, 2009: Standard method of test for softening point of bitumen (ring-and-ball apparatus). American Association of State and Highway Transportation Officials

40. AASHTOT 48 (2018) 2018 Edition, 2018: Standard method of test for flash point of asphalt binder by cleveland open cup. American Association of State and Highway Transportation Officials

41. AASHTO T 51-09 (2018) Standard method of test for ductility of asphalt materials. American Association of State and Highway Transportation officials, 2018.

42. AASHTO T 209-12 (2016) Standard method of test for theoretical maximum specific gravity $(\mathrm{Gmm})$ and density of hot-mix asphalt (HMA). American Association of State and Highway Transportation Officials, 2012.

43. AASHTOT 166-16 (2020) Standard method of test for bulk specific gravity (Gmb) of compacted hot mix asphalt (HMA) using saturated surface-dry specimens. American Association of State and Highway Transportation Officials, 2016.

44. AASHTO, T-166 (2016) Standard method of test for bulk specific gravity $(\mathrm{Gmb})$ of compacted hot mix asphalt (HMA) using saturated surface-dry specimens. American Association of State Highway and Transportation Officials, Washington, DC. https://global. ins.com/doc_detail.cfm?document_name=AASHTO\%20T\%20166 \&item_s_key=00489063

45. AASHTO, T 245 (2015) Standard method of test for resistance to plastic flow of asphalt mixtures using Marshall apparatus. American Association of State Highway and Transportation Officials, Washington, DC. https://global.ihs.com/doc_detail.cfm?docum ent_name=AASHTO\%20T\%20245\&item_s_key $=00489117$

46. AASHTO, T-324 (2008) Standard method of test for Hamburg wheel-track testing of compacted hot-mix asphalt (HMA). American Association of State Highway and Transportation Officials, Washington, DC. https://global.ihs.com/doc_detail.cfm?docum ent_name=AASHTO\%20T\%20324\&item_s_key=00489231\#abstr act-section 
47. AASHTO R-30 (2002) Standard Practice for mixture conditioning of hot-mix asphalt (HMA). American Association of State Highway and Transportation Officials, Washington, DC. https://www.in.gov/ indot/div/mt/aashto/testmethods/aashto_r30.pdf

48. Khan KM, Kamal MA (2012) Rutting based evaluation of asphalt mixes. Pak J Eng Appl Sci 11:60-65

49. Sabat AK (2012) Utilization of bagasse ash and lime sludge for construction of flexible pavements in expansive soil areas. Elect J Geotech Eng 17:1037-1046. https://www.researchgate.net/
publication/267229117_Utilization_of_Bagasse_Ash_and_Lime_ Sludge_for_Construction_of_Flexible_Pavements_in_Expansive_ Soil_Areas

Publisher's Note Springer Nature remains neutral with regard to jurisdictional claims in published maps and institutional affiliations. 